\title{
FROM DRAWING COGNITIVE MAPS TO KNOWING THE PROTECTION ZONES FOR DRINKING WATER RESOURCES
}

\section{Z RISANJEM SPOZNAVNIH ZEMLJEVIDOV DO POZNAVANJA VARSTVENIH PASOV VIROV PITNE VODE}

Aleš Smrekar

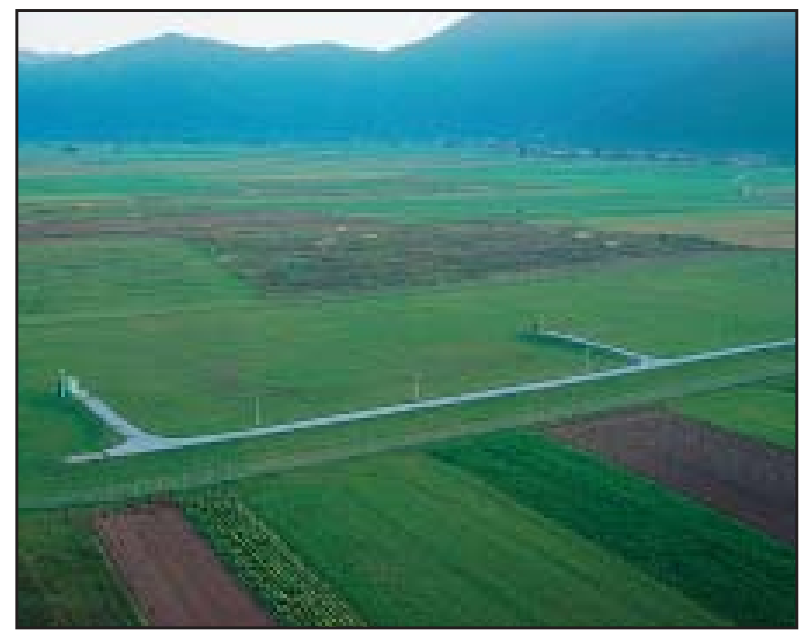

Brest water pumping station (photograph: Aleš Smrekar). Vodarna Brest (fotografija: Aleš Smrekar).

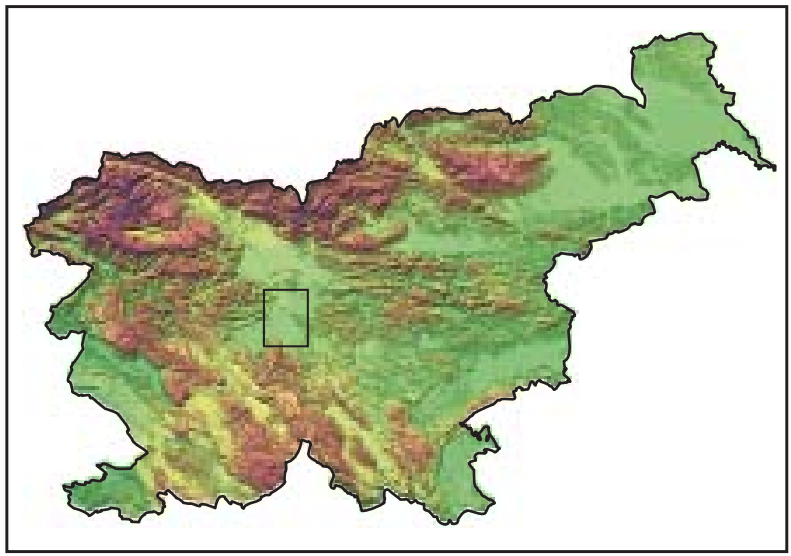




\section{From drawing cognitive maps to knowing the protection zones for drinking water resources}

UDC: $628.1: 912(497.4)$

COBISS: 1.01

ABSTRACT: Using a sample of 900 persons from the urban area of Ljubljansko polje and the suburban area of Iški vršaj, we tried to determine how much local residents knew about the protection zones for drinking water resources. We employed a survey questionnaire and the drawing of cognitive maps. A little fewer than half of the people are aware they live in water protection zones. The proportions of those who are aware of the protection zones in Ljubljansko polje (two fifths) and in Iški vršaj (two thirds) differ considerably. Only 280 persons, just under one third of those surveyed, drew the boundaries of the protection zones on the attached map. In Ljubljansko polje, the greatest concentration of drawn protection zones was a little north of the oldest and largest pumping station at Kleče. The second largest condensation occurred in Iški vršaj in the immediate vicinity of the Brest pumping station.

KEY WORDS: drinking water, water-protection area, questionnaire, cognitive map, Ljubljansko polje, Iški vršaj, Slovenia.

The article submitted for publication on February 27, 2006.

ADDRESS:

Aleš Smrekar, Ph. D.

Anton Melik Geographical Institute

Scientific Research Centre of the Slovenian Academy of Sciences and Arts

Gosposka ulica 13, 1000 Ljubljana, Slovenia

E-mail: ales.smrekar@zrc-sazu.si

\section{Contents}

1 Introduction 9

2 Methods 11

3 Results 13

3.1 Awareness of protection zones for drinking water resources - questionnaire 13

3.2 Familiarity with protection zones for drinking water resources - cognitive maps $\quad 15$

4 Conclusion 22

5 References 23 


\section{Introduction}

Ensuring a sufficient amount of drinking water in Europe and Slovenia depends primarily on the reserves of groundwater. We know that very diverse interests occur and often conflict on alluvial plains over the largest reserves of drinking water, but appropriate water management programs can provide the monitoring and directing of encroachments on the land (Kladnik et al. 2002; Rejec Brancelj 2003; Urbanc, Breg 2005).

The relationship between urban land use and the protection of drinking water resources ranks among the most distinct modern spatial conflicts. The more a city and its functions develop, the more affected are the quality and quantity of water resources suitable for drinking.

The rich reserves of groundwater in the immediate vicinity and even below a large part of Ljubljana, estimated at 100 million $\mathrm{m}^{3}$ with dynamic reserves (the value of the lowest volume of flow) of $2 \mathrm{~m}^{3} / \mathrm{sec}$, are a natural resource of regional importance (Rejec Brancelj et al. 2005). More than a century after the installation of a central waterworks system, the groundwater of Ljubljansko polje is still the most important source of drinking water for the supply of Ljubljana. It provides $90 \%$ of the required quantity while the remaining $10 \%$ is pumped from the Iški vršaj aquifer near the settlement of Brest on the southern edge of the Ljubljansko Barje moor, an area outside the City Municipality of Ljubljana in the neighbouring municipality of Ig.

Drinking water from the groundwater of Ljubljansko polje is extracted by four pumping stations: Kleče, Šentvid, Hrastje, and Jarški prod. The first two are on the western part of Ljubljansko polje between compactly built-up urban land to the south, west, and east, and the Sava River to the north. Between these two stations are the still active farming settlements of Kleče and Savlje. The Hrastje pumping station is located in the eastern part of Ljubljansko polje between the Moste industrial zone to the south and Šmartinska cesta street to the right bank of the Sava River. The Jarški prod pumping station is located on the left bank of the Sava River south of the Črnuče industrial zone that runs west to east between Črnuče and Nadgorica. The fifth pumping station supplying Ljubljana is in the Iški vršaj area of the Ljubljansko Barje moor, the Brest pumping station located south of the settlement of the same name.

The water protection zones around pumping stations in Ljubljansko polje were first defined by decree in 1955 (Odlok... 1955). They proved decisive for the protection of the water resource because they limited the spread of the city in the vicinity of pumping stations (Breznik 1988). The boundaries were respected relatively consistently, but after 1966 the construction of individual houses and new neighbourhoods was permitted; thus appeared the eastern part of Savlje, the southern part of Kleče, part of Tomačevo, and the industrial zone along Letališka cesta street. A new decree on water protection zones was passed in 1977 (Odlok ... 1977) that also defined the protection zone around the Jarški prod pumping station. In addition, wider (third) and influence (fourth) protection zones were defined that included areas from which water percolates or flows directly into the groundwater. Because their priority was not protection, the construction of homes and other buildings connected to the public sewage system and protected from the seeping of harmful substances into the groundwater was allowed in these zones.

The protection zones for drinking water resources in Ljubljansko polje and for the first time in Iški vršaj discussed in this paper were defined in 1988 by the Decree on the Protection of Drinking Water Resources (Odlok... 1988), which compared with the previous decree did not bring any substantial changes to Ljubljansko polje. This decree still applies for Iški vršaj, while in 2004 a new Decree on the Water Protection Area for the Ljubljansko polje Aquifer was passed for the Ljubljansko polje area (Uredba ... 2004).

Water protection areas are divided into three protection zones for drinking water resources:

- the first or narrowest protection zone is devoted exclusively to the areas immediately surrounding installations for the supply of drinking water (41.35 ha in Ljubljansko polje and 13.8 ha in Iški vršaj);

- the second or narrow protection zone with a strict protection regime is intended for the direct protection of pumping stations from pollution (total 1,942.71 ha in Ljubljansko polje and 520.7 ha in Iški vršaj);

- the third or wider protection zone with a moderate protection regime is devoted to protecting the flow of groundwater toward the pumping stations (total 3,618.95 ha in Ljubljansko polje and 521.3 ha in Iški vršaj);

A comprehensive approach of water management aims at economic efficiency on one hand and sustainable management on the other. Documents that discuss achieving social consensus on environmental decisions by including all interest groups in the decision-making process are increasingly important. 


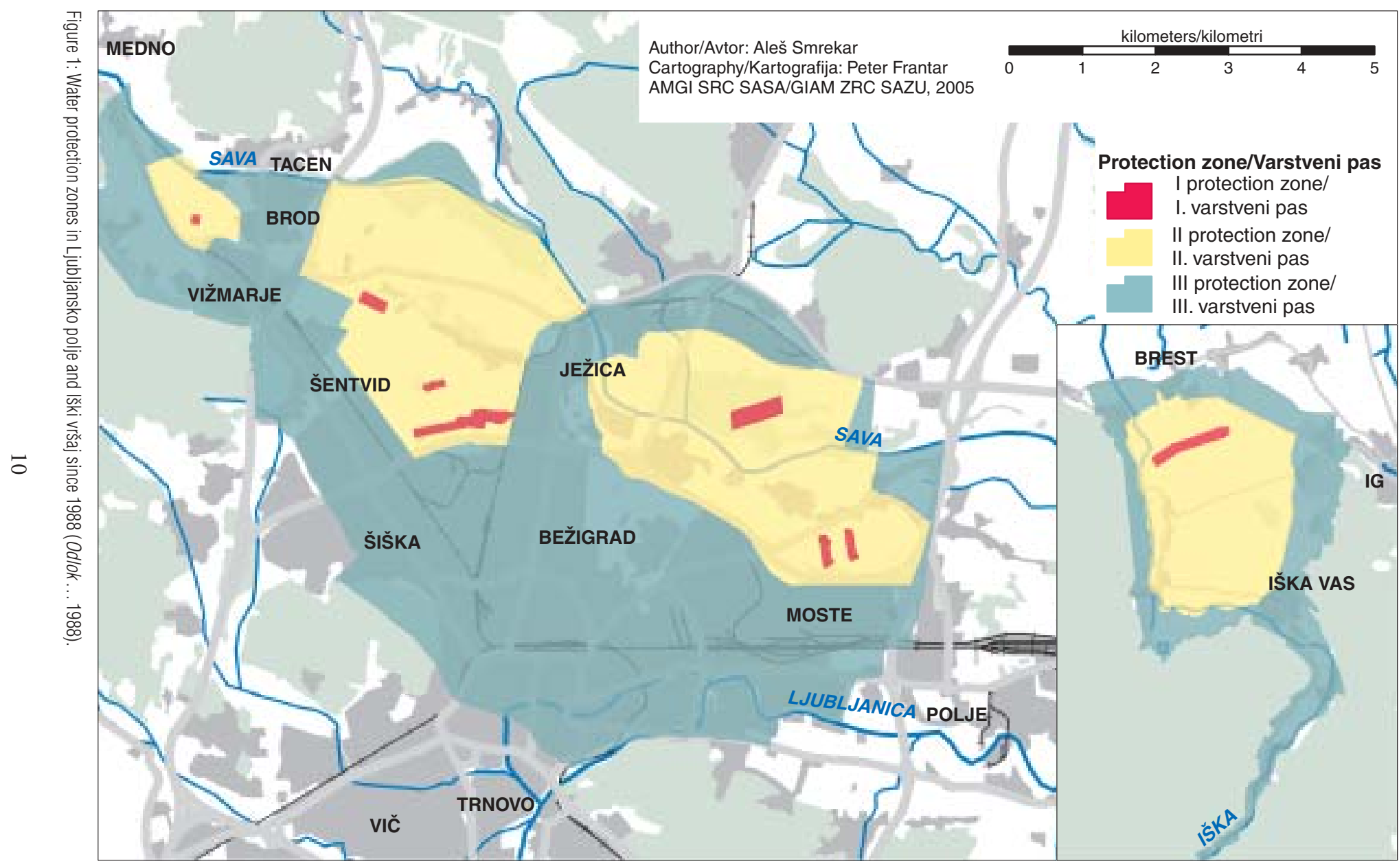


An environmental awareness of water as a natural resource is a precondition for active cooperation in decision-making processes regarding land use plans and for the preservation and protection of quality water resources and water in general.

It is generally assumed that the population of Ljubljana and its surroundings is sufficiently environmentally aware. However, this stereotype is soon refuted when we consider the numerous illegal waste dumps, porous septic tanks and dung pits, the unsuitable use of phytopharmaceutical substances in agriculture, and the unsupervised individual pumping of water (Kladnik 2002; Rejec Brancelj 2000; Kladnik et al. 2003; Smrekar in Kladnik 2004; Breg et al. 2005), all of which are significantly influenced by the actions of individuals. Experience thus far indicates that environmental awareness is closely linked to the socioeconomic structure, but it is also the result of long-term success in providing information and educating the population. We consider the population to be the agent and the beneficiary or victim of changes in the environment and an active or passive transformer of the landscape.

In this study, we set ourselves the goal of determining and assessing public awareness of the protection zones for drinking water resources.

\section{Methods}

In the context of a broader research project (Smrekar 2005), we tried to determine, among other things, how local residents perceive the environment in which they live. Since the people surveyed came from various areas, we were able to determine differences and similarities between specific groups and, above all, the reasons for greater or lesser environmental awareness.

We were also interested how familiar local residents are with the protection zones for drinking water resources and therefore employed a combined survey method using a questionnaire and cognitive maps.

In the broader research project, we studied the population supplied by drinking water via the Ljubljana waterworks system. In the period of the study (2003 and 2004), the included population lived in the protection zones for drinking water resources in Ljubljansko polje and Iški vršaj (Odlok... 1988) or their vicinity.

A questionnaire is a method of gaining an empirical insight into a selected population and its patterns (Toš 1988). Our sample included 900 people. Two thirds of the questionnaires were given out in the urban environment of Ljubljansko polje and one third in the suburban environment in Iški vršaj. One third (300) of the questionnaires were given to "active « burdeners of groundwater in the narrower protection zones (100 farmers and 100 allotment holders in Ljubljansko polje and 100 farmers in Iški vršaj), one third (300) to "passive « burdeners (people who only reside in these areas) in the wider protection zone, and one third (300) to users of drinking water from the studied pumping stations who do not live in the protection zones. We achieved a representative pattern of the study population by following two demographic criteria, age and gender.

The study also included the method of cognitive maps, which previously has rarely been employed in geography (Gams et al. 1993; Klemenčič 2002; Natek 2002a; Natek 2002b) and is more often used by psychologists. Along with primarily theoretical speculations, cognitive maps appeared and were used mostly because of practical planning questions. They referred mainly to land use and the distribution of resources as well as to links with conceptions about the environment. Among other things, cognitive maps employed in studies of relationships between people and the environment can contribute to a more reasonable use of natural resources, encourage individuals to become involved in development and planning of a more efficient implementation of changes, and help in the preservation and recording of perceptions of the environment (Polič 2002; after Wyhte).

Cognitive maps, a procedure through which we try to establish how people conceptualize the spatial relationships and characteristics of their environment, can be an important means of acquiring the information necessary to establish the situation, and on this basis, for further planning. Cognitive maps offer at least two types of information:

- directly perceptible experience, and

- cognitive processing of personal experience.

There are many methods. We decided to acquire our information using a socio-spatial form. This is a more structured type of research using cognitive maps. The people surveyed were asked to encircle the area they believed was a protection zone for drinking water resources for the supply of the population. 


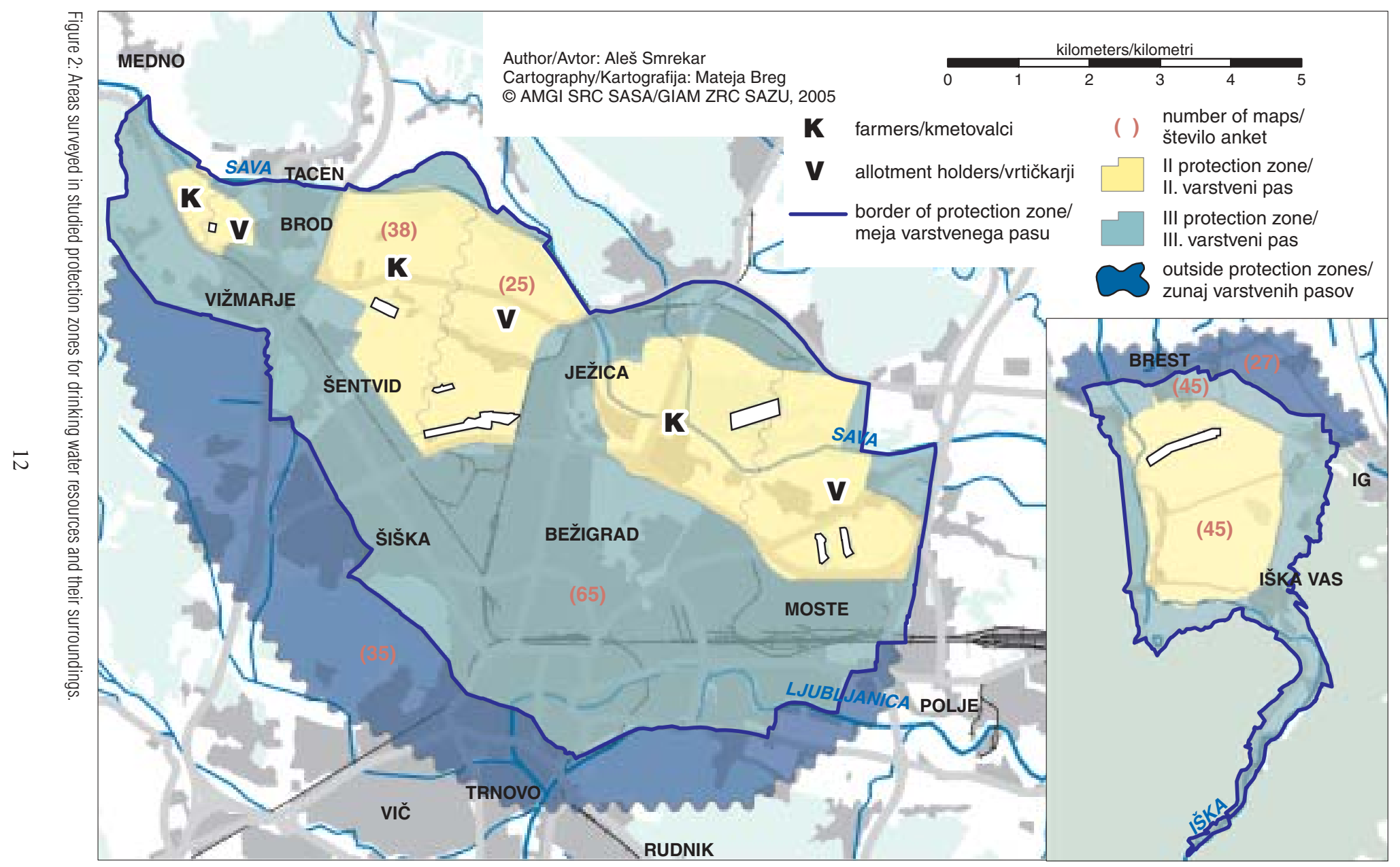


In drawing such maps, individuals' drawings of the environment appear as the results of their previous knowledge of maps containing location information (boundaries of protection zones). Individuals' drawings of the environment correspond with their perceptions of land use. We distinguish geographi$\mathrm{cal}$ and behavioural environments because those living in the same geographical environment live in different behavioural environments and acquire information using all the senses (Polič 2002).

Along with answering the questions asked in the survey, we asked each of those questioned to draw the boundary of a protection zone or the boundaries of several zones of drinking water resources supplying the inhabitants of Ljubljana and its surroundings on a black-and-white, A3 format, approximately 1:73,000-scale map of the wider Ljubljana area covering the area between Zbilje in the northwest, Prevoje pri Šentvidu in the northeast, Smrekovec near Rakitna in the southwest, and the Kremenica hill near Predole in the southeast. Before presenting the maps, we explained to those surveyed that the groundwater is protected from pollution by the Decree on the Protection of Drinking Water Resources and that it is necessary to ensure suitable conditions for the quality and quantity of healthy water.

Some 280 persons or just under a third $(31.1 \%)$ of the 900 people surveyed attempted to draw the boundaries of the water protection zones. Of these, 163 or about one quarter $(27.1 \%)$ of the total survey group were from Ljubljansko polje and produced just under three fifths or $58.2 \%$ of all the drawings) while 117 or just under two fifths (39.0\%) were from Iški vršaj and produced two fifths or $41.7 \%$ of all the drawings. We consider this a relatively good response because the question was intended only for those who are actually supposed to know where the boundaries of the water protection zones run.

The cartographic material was prepared using the ARC GIS computer program.

\section{Results}

\subsection{Awareness of protection zones for drinking water resources - questionnaire}

The key document in establishing how familiar those surveyed are with the study topic is the Decree on the Protection of Drinking Water Resources (Odlok... 1988), which included Ljubljansko polje and Iški vršaj. Since our survey was made in 2003 before the passing of the latest decree that applies just to Ljubljansko polje, this study considers the former boundaries of the water protection zones. After more than fifteen years of the decree's existence, we asked those surveyed whether they live (or have a garden allotment) in the water protection zone for the supply of Ljubljana and its surroundings established by the decree.

From the answers of all those surveyed (from within and outside the protection zones), we found that 439 people or $48.8 \%$ answered correctly, certain they do or do not live or have gardens in water protection zones. Half of those who live outside the water protection zones (50.5\% in Ljubljansko polje and $47.0 \%$ in Iški vršaj) responded that they do not live in water protection zones. Almost one third $(31.2 \%)$ did not know the answer to the question.

Analyzing the figures for just the water protection zones, we found that just under half of these people $(48.5 \%)$ were aware they lived in a water protection zone. The proportions of those who know this in Ljubljansko polje (only 39.0\%) and Iški vršaj (67.5\%) differ greatly. Farmers are most aware that they live in protection zones; however, the percentages for the two areas are reversed with more than three quarters in Ljubljansko polje (77.0\%) aware compared with just over two thirds in Iški vršaj (68.0\%). It is obvious that farmers in Ljubljansko polje are more affected by various public services and therefore know exactly where they live. Farmers in Iški vršaj are less familiar with the boundaries. This is probably the result of less intensive cooperation with various services and the lack of intermunicipal cooperation between the City Municipality of Ljubljana and Municipality of Ig.

The explanation for the lower proportion of correct answers among allotment holders $(56.0 \%)$ lies in the fact that these those surveyed have a poor knowledge of the areas where they have their gardens, which are frequently far from their place of residence. The lowest proportion of correct answers occurred in the wider protection zone in Ljubljansko polje: only a little more than a tenth of the people $(11.5 \%)$ were aware they lived in a water protection zone, while more than a third $(36.5 \%)$ did not believe they lived in a protection zone at all. While the people in Ljubljansko polje are somewhat familiar with the narrow protection areas around the pumping stations, which they know or at least assume are areas protected by law, the wider protection areas for the pumping stations are too distant to have any connection in their minds. It is quite clear that they are not systematically informed about the areas in which they live. 


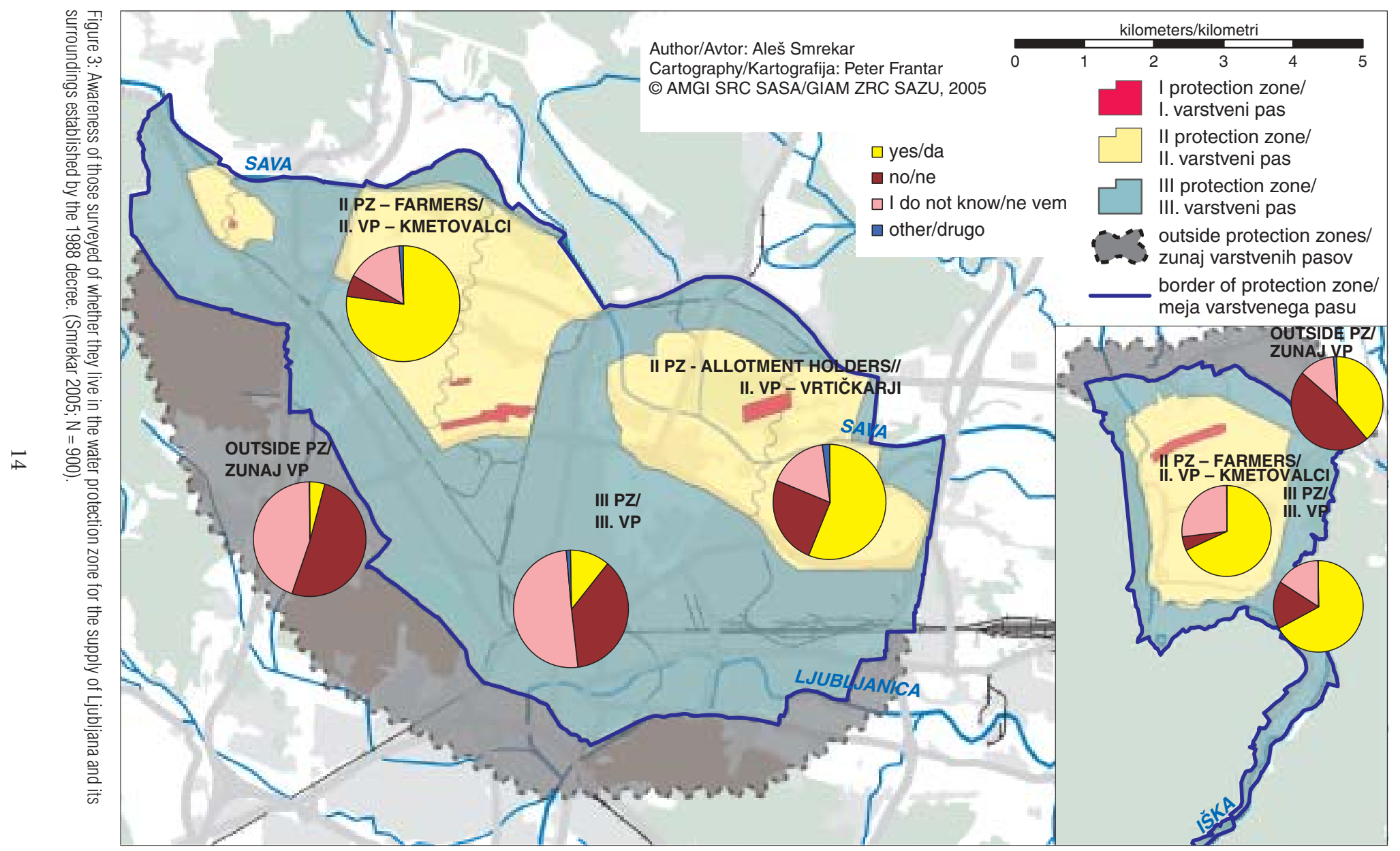


We expected those surveyed who answered whether they lived in a water protection zone to be able to state the name of the zone correctly. However, the proportion of those who at least approximately stated the correct name (name of pumping station, area, or entire protection zone) was just above one quarter $(26.5 \%)$, and of these, in spite of the half smaller sample, almost half were from Iški vršaj (45.5\%). Names considered correct included Ljubljanski vodovod (»Ljubljana Waterworks«), Barje, Iški vršaj, Brest, Ig, and Matena for the Iški vršaj area and Ljubljanski vodovod, Ljubljana, Šentvid, Stegne, Kleče, Savlje, Črnuče, Jarški prod, Savski prod, and Hrastje for the Ljubljansko polje area. The farmers of Iški vršaj contributed a surprisingly low proportion of approximately correct names $(36.0 \%)$, and those surveyed in the wider water protection zones in Ljubljansko polje were practically without correct answers (3.0\%).

\subsection{Familiarity with protection zones for drinking water resources - cognitive maps}

With this inquiry we wished to determine whether the residents of the studied areas know that they live in areas that are protected by law as areas for the protection of drinking water resources. This time, however, we were interested not only in their behaviour but primarily in their knowledge of the boundaries.

Using cognitive maps we acquired cognitive processing of personal experience. Some 280 of the 900 people surveyed, just under one third (31.1\%), contributed maps. Of the 280 boundaries of protection zones drawn, six tenths are from Ljubljansko polje (58.2\%) and four tenths from Iški vršaj (41.8\%). Although this ratio does not reflect the ratio of questionnaires filled out in the two study areas (600:300), it is more advantageous from the viewpoint of interpretation since it would be more difficult to visually distinguish between two thirds of drawn boundaries of those surveyed from Ljubljansko polje and one third from Iški vršaj. Furthermore, given the answers of those surveyed to whether they live in a protection zone covered by a decree, the number of boundary drawers from the two areas is not surprising.

Table 1: Survey participants who drew boundaries of water protection zones for the supply of Ljubljana and its surroundings (Smrekar 2005; $\mathrm{N}=280$ ).

\begin{tabular}{|c|c|c|c|}
\hline & $\begin{array}{l}\text { Total } \\
\text { participants }\end{array}$ & $\begin{array}{l}\text { Proportion of participants of all } \\
\text { those surveyed in group (\%) }\end{array}$ & $\begin{array}{l}\text { Proportion of participants } \\
\text { of all those surveyed (\%) }\end{array}$ \\
\hline \multicolumn{4}{|l|}{ Ljubljansko polje } \\
\hline Farmers & 38 & $38.0 \%$ & $4.2 \%$ \\
\hline \multicolumn{4}{|l|}{ Ljubljansko polje } \\
\hline Allotment holders & 25 & $25.0 \%$ & $2.8 \%$ \\
\hline \multicolumn{4}{|l|}{ Ljubljansko polje } \\
\hline narrower protection zone - total & 63 & $31.5 \%$ & $7.0 \%$ \\
\hline \multicolumn{4}{|l|}{ Ljubljansko polje } \\
\hline Wider protection zone & 65 & $32.5 \%$ & $7.2 \%$ \\
\hline \multicolumn{4}{|l|}{ Ljubljansko polje } \\
\hline Narrower and wider protection zone & 128 & $32.0 \%$ & $14.2 \%$ \\
\hline \multicolumn{4}{|l|}{ Ljubljansko polje } \\
\hline Outside protection zones & 35 & $17.5 \%$ & $3.9 \%$ \\
\hline \multicolumn{4}{|l|}{ Ljubljansko polje } \\
\hline Total & 163 & $27.2 \%$ & $18.1 \%$ \\
\hline \multicolumn{4}{|l|}{ Iški vršaj } \\
\hline Narrower protection zone & 45 & $45.0 \%$ & $5.0 \%$ \\
\hline \multicolumn{4}{|l|}{ Iški vršaj } \\
\hline wider protection zone & 45 & $45.0 \%$ & $5.0 \%$ \\
\hline \multicolumn{4}{|l|}{ Iški vršaj } \\
\hline Narrower and wider protection zone & 90 & $45.0 \%$ & $10.0 \%$ \\
\hline \multicolumn{4}{|l|}{ Iški vršaj } \\
\hline Outside protection zones & 27 & $27.0 \%$ & $3.0 \%$ \\
\hline \multicolumn{4}{|l|}{ Iški vršaj } \\
\hline Total & 117 & $39.0 \%$ & $13.0 \%$ \\
\hline Total & 280 & $31.1 \%$ & $31.1 \%$ \\
\hline
\end{tabular}




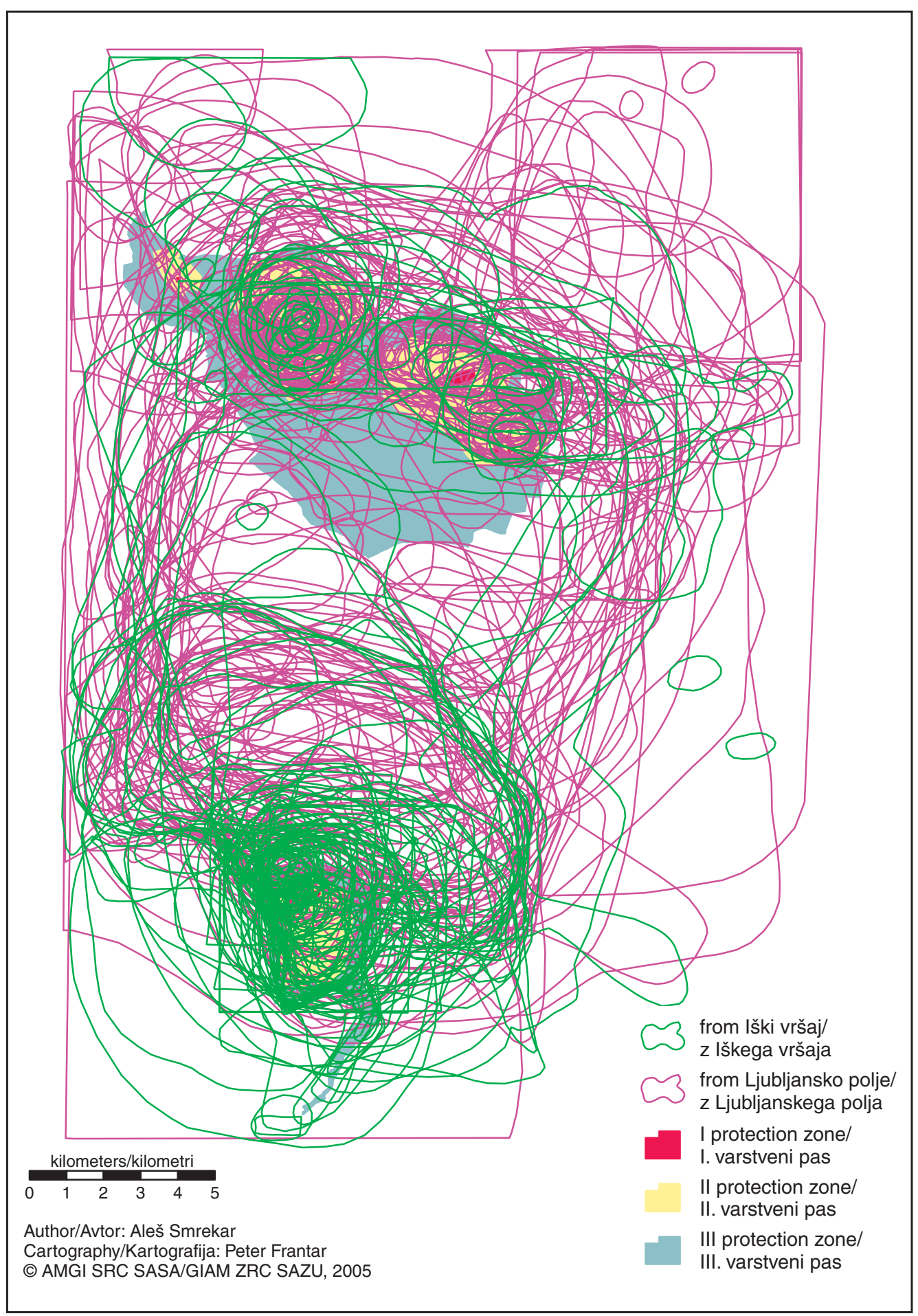

Figure 4: Water protection zones for the supply of Ljubljana and its surroundings, as drawn by all those surveyed (Smrekar 2005; N = 280). 
A look at the map of all drawn areas shows certain concentrations. In Ljubljansko polje, the largest concentration is in the area of the settlement of Kleče, north of the Kleče pumping station, with a large concentration of answers. The concentration spreads relatively concentrically but with a very small cross-section from the settlement toward the Kleče and Šentvid pumping stations. The latter is merely a coincidence since other answers indicate that the population is largely unaware of the Šentvid pumping station. The concentration »cloud « becomes quite scattered toward the southeast, but it again becomes detectable in the shape of a less intensely concentrated ellipse around the Hrastje pumping station. North of it, on the left bank of the Sava River, a careful observer will notice a less distinct but still recognizable ellipse around the Jarški prod pumping station. Two overlapping elliptical shapes are probably the consequence of the visible spatial boundary represented by the Sava River. We could also join them as one uniform, less dominant circle, like the one spread around the Kleče pumping station.

The southern part of Ljubljansko polje, we could say the majority of the wider protection zone, is not rooted in the consciousness of people as a protected area. If those surveyed drew the boundaries of protection zones quite widely, in addition to Ljubljansko polje the majority of cases also included elevations such as Rožnik, Castle Hill, and part of Golovec and on Ljubljansko Barje moor approached the northern edge of Iški vršaj.

The second strongest concentration is observed in Iški vršaj in the immediate vicinity of the Brest pumping station, with boundaries concentrated in the west along the foot of the Krim hills. Those surveyed apparently believe that the edge between the flat and elevated areas represents the boundary of the protection zone. Slightly blurred although still relatively distinct, the concentration »cloud « spreads toward south and east of the alluvial fan. It is interesting that the »cloud « reaches well onto the Ljubljansko Barje moor, reaching the eastern part of Ig and all the way to the southern Ljubljana expressway in the north. Those surveyed less frequently link Iški Vintgar with the protected area.

Analysis of answers according to individual groups is even more interesting. Those surveyed in the narrower protection zone, the farmers and garden allotment holders, obviously know where the narrower protection zones are located but often equate them with the external boundaries of protection zones.

There are major concentrations of lines in the shape of a circle near the settlement of Kleče and two ellipses near the Hrastje and Jarški prod pumping stations. The wider protection zone is less distinctly perceptible.

Another concentration is perceptible south of Ljubljana that is widely disposed with its center gravitating north from Iški vršaj to the area of Črna vas and Lipe. Farmers drew the boundary very widely; and in some cases it reaches from the southern edge of Ljubljansko polje all the way to the southern edge of Iški vršaj. Among allotment holders, this boundary is substantially more concentrated in a narrow zone from the center of the Ljubljansko Barje moor to the center of Iški vršaj, but with a smaller number of repetitions.

Those surveyed from the wider water protection zone of Ljubljansko polje see the boundary of the protection area quite differently. Here, no concentrations on smaller areas are perceptible, with rare exceptions in the vicinity of the Kleče pumping station. Mainly we can trace a large vertical ellipse drawn from the northern edge of Ljubljansko polje to the southern edge of Iški vršaj with the perceptible distinction of two areas around the center of the Ljubljansko Barje moor.

Only $17.5 \%$ of those surveyed from the edge of Ljubljansko polje who live outside the water protection zones were prepared to draw the boundaries. It appears they know the location of the Brest pumping station (from where they receive the majority of water) relatively well, they know somewhat less about Hrastje and Jarški prod, and by drawing one circle around the Kleče and Šentvid pumping stations they probably again proved that they do not know the exact location of the Kleče pumping station, much less the one at Šentvid. To generalize, we determined that they reduced the protection zones in Ljubljansko polje mostly to their northern and eastern sides along the Sava River and expanded the protection zones in Iški vršaj in a conical shape northwards all the way to the center of the Ljubljansko Barje moor.

Those surveyed from the narrower water protection zone in Iški vršaj showed highly unusual knowledge of protection zones, especially in their local area. Given their very solid knowledge of the fact that they live in a protection zone, we would expect that they have a clear spatial picture as well. However, in comparison with the farmers from Ljubljansko polje who limited themselves to drawing boundaries in the immediate vicinity of the pumping stations, the farmers in Iški vršaj only occasionally drew the immediate surroundings of the Brest pumping station. Along the western and southern edge of Iški vršaj, the drawings as a rule reach the foot of the Krim hills, although they frequently also stretch southeast high into the hills. The area bordered to the north stretching almost to the southern Ljubljana expressway and 


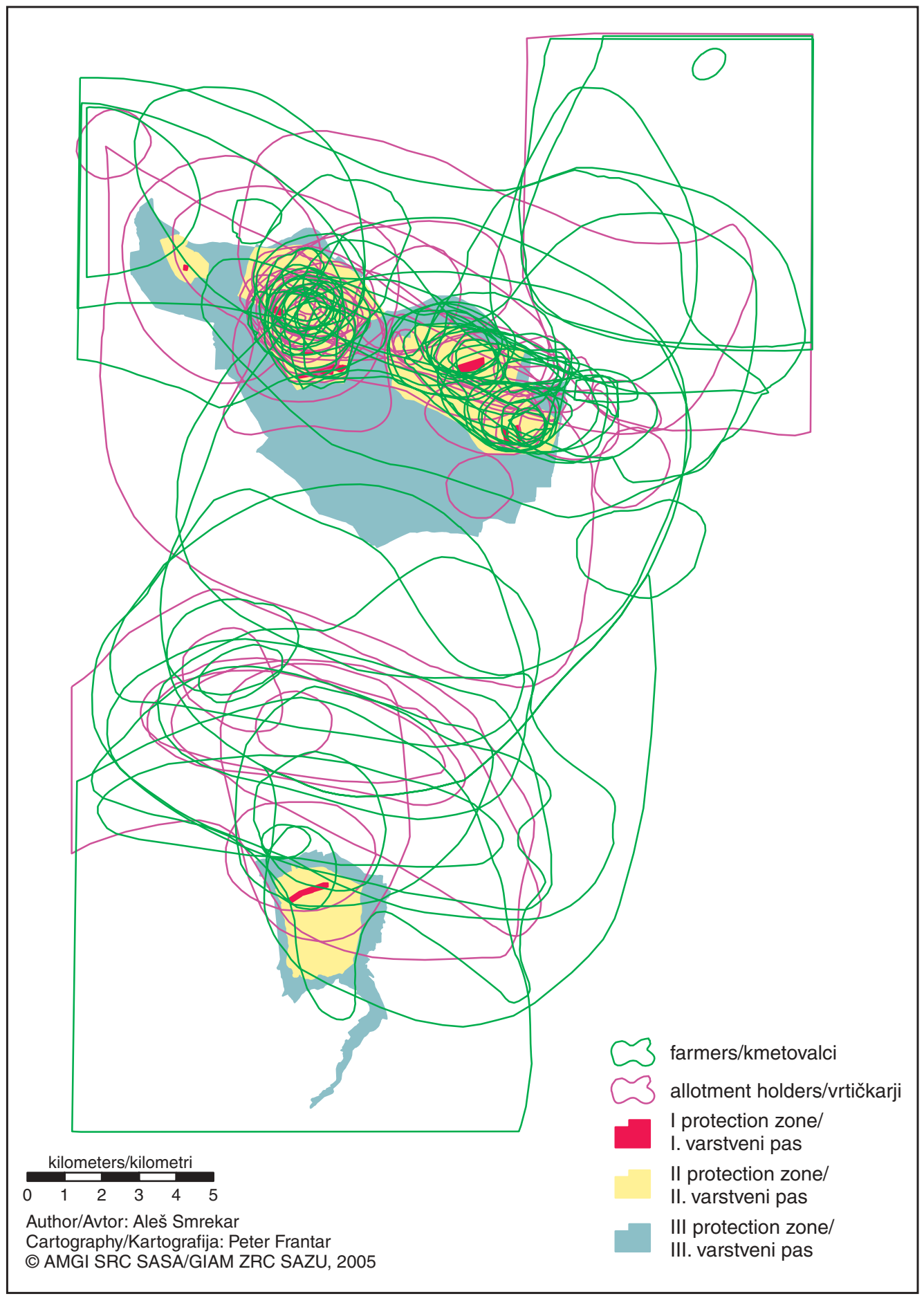

Figure 5: Water protection zones for the supply of Ljubljana and its surroundings, as drawn by surveyed farmers and allotment holders from Ljubljansko polje. (Smrekar 2005; $\mathrm{N}=63$ ). 


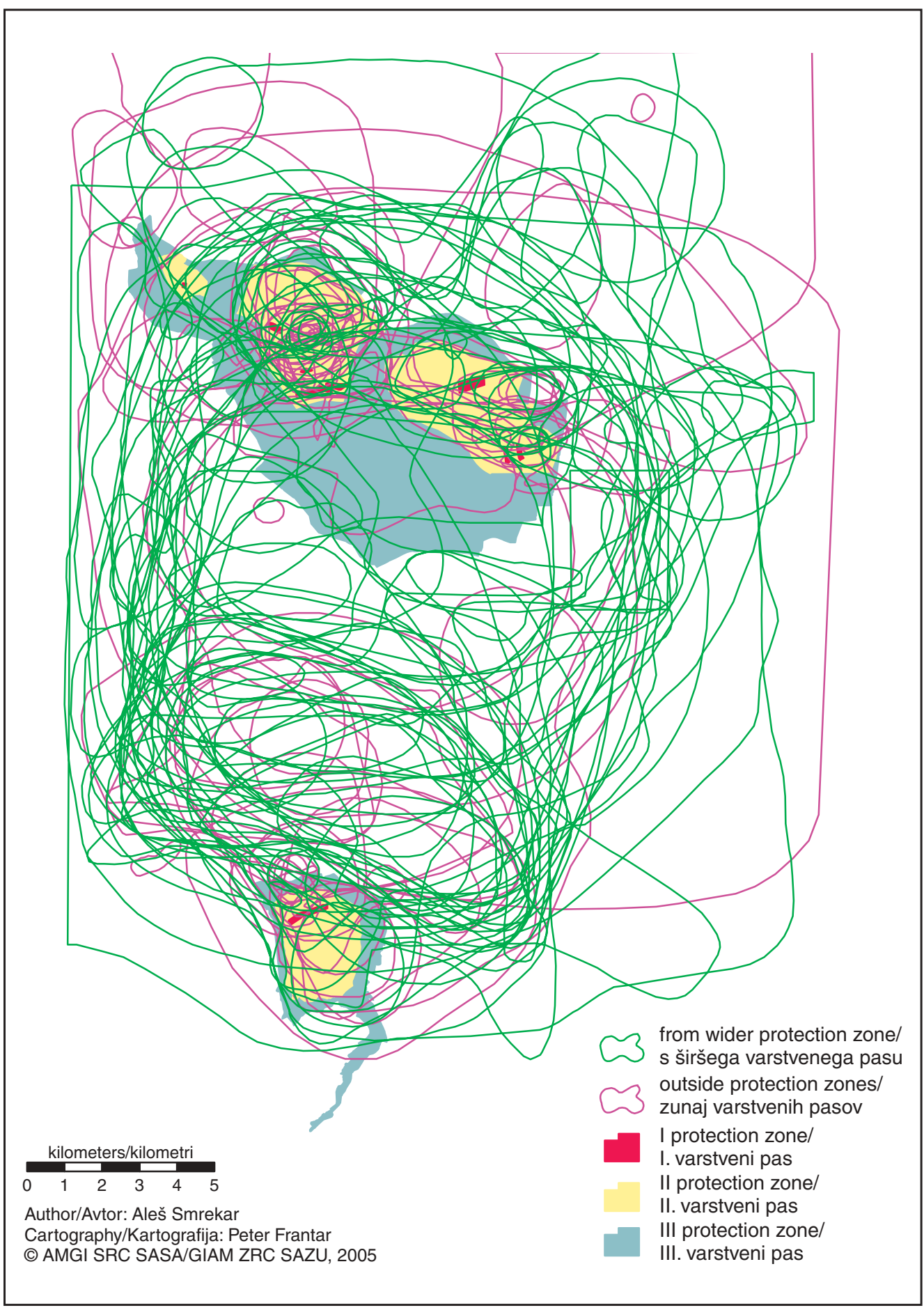

Figure 6: Water protection zones for the supply of Ljubljana and its surrounding, as drawn by those surveyed from the wider water protection zone of Ljubljansko polje and outside it (Smrekar 2005; $\mathrm{N}=100$ ). 


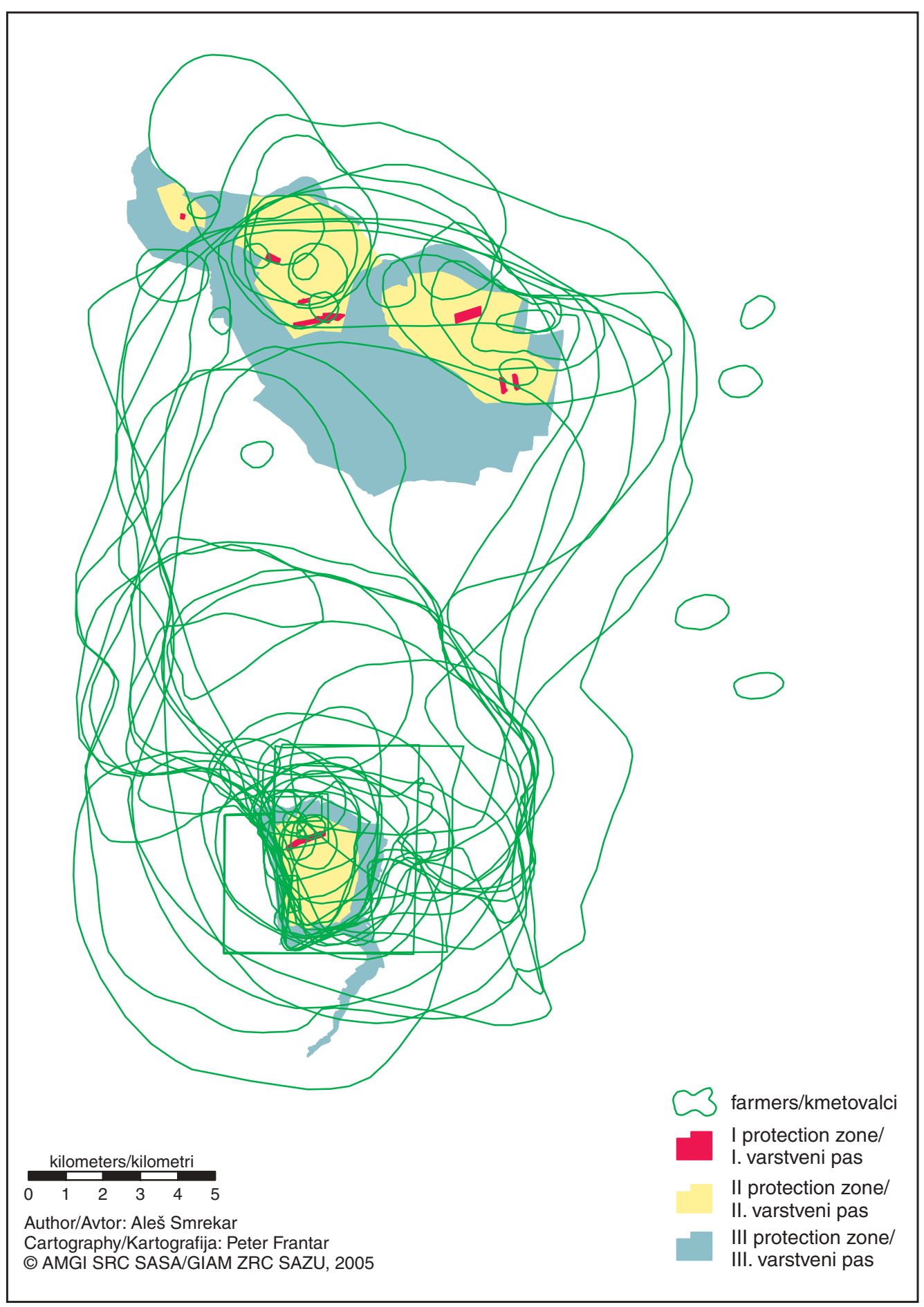

Figure 7: Water protection zones for the supply of Ljubljana and its surroundings, as drawn by farmers from ľ̌ki vršaj (Smrekar 2005; N = 45). 


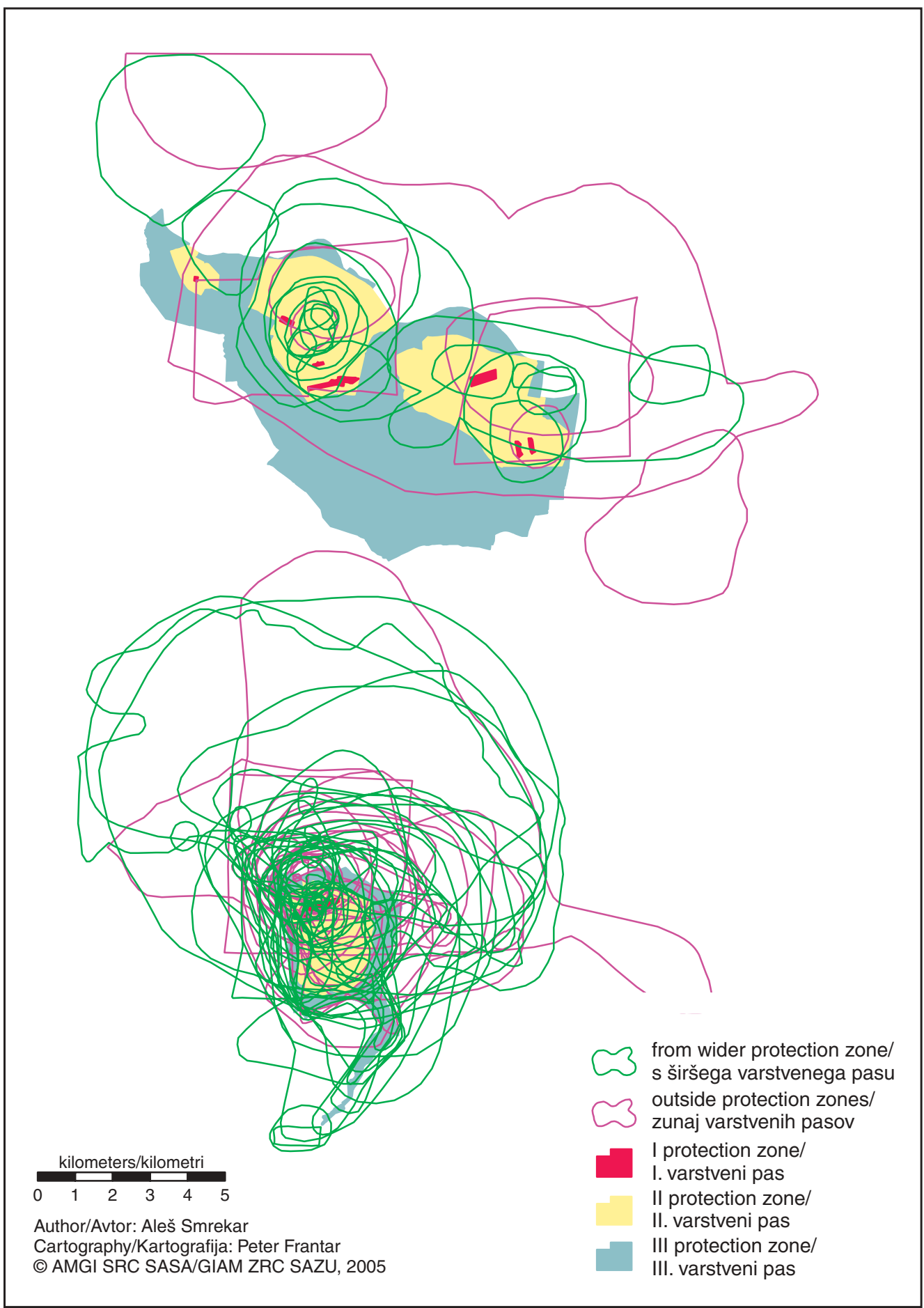

Figure 8: Protection zones of drinking water resources for the supply of Ljubljana and its surroundings, as drawn by those surveyed from the wider lški vršaj water protection zone and outside it (Smrekar 2005; N =72). 
to the west where it almost reaches the western edge of Vnanje Gorice is often surprisingly wide. The second boundary concentration is in the wider zone of the Sava River in Ljubljansko polje with distorted boundaries between individual narrow areas of the pumping stations. Surprisingly many farmers from Iški vršaj view Iški vršaj and Ljubljansko polje as a unified protection area that includes the Ljubljansko Barje moor located between them, but apparently none of them are aware that the protection zone in Iški vršaj also reaches deep into Iški Vintgar.

Those surveyed from the wider Iški vršaj water protection zone are surprisingly well informed, perhaps the most among the studied groups, about their protection zone. The western and southern boundaries, as well as the part stretching toward Iški Vintgar, are often drawn very accurately, while to the north and east the boundaries spread outwards. In just a few cases the boundary is liberally drawn toward the center of the Ljubljansko Barje moor, but none of them links this area with Ljubljansko polje in one uniform protection area. According to those who believe that Ljubljansko polje is a protected zone, the boundary in Ljubljansko polje obviously runs exclusively along the Sava River with specially demarcated areas around the pumping stations.

Only a quarter (27.0\%) of those surveyed outside water protection zones from the edge of Iški vršaj responded to the request to draw the boundaries, and these revealed a very poor knowledge of the conditions in Ljubljansko polje since as a rule they drew the boundaries too far toward the north and east. Their knowledge of the situation in Iški vršaj is much better, although here too - which is interesting - they often drew the area more toward east and north since they obviously believed that they themselves lived in the protection area.

Those with elementary school education drew one fifth $(21.2 \%)$ of all the cognitive maps, while representatives of the other three education groups drew about three tenths each $(32.8 \%, 29.6 \%$, and 30.5\%). We did not manage to identify any significant deviations between different groups regarding knowledge of protection zones.

\section{Conclusion}

The results indicate that a much higher proportion of those surveyed in Iški vršaj know that they live in water protection zones than those in Ljubljansko polje. This is probably the consequence of smaller protection areas and the proximity of pumping stations as important objects in their area. In contrast, Ljubljansko polje has a five time larger protected area that loses importance in the consciousness of people with distance from the pumping stations; furthermore, pumping stations do not stand out as much in an urban environment as they do in a more rural setting.

The lack of knowledge of farmers in Iški vršaj is alarming since we know that agricultural advisors constantly inform them about activities allowed in protection zones. Undoubtedly, they are less exposed to the even more aggressive pressures from various professional services experienced by the farmers in Ljubljansko polje reflected by their better knowledge of the decree.

Cognitive maps are certainly an appropriate supplement to classical geographical surveys. That the response was not high is probably the consequence of the modest spatial image of people in general and probably in particular of their unfamiliarity with the problem presented. Certain generalities appeared. In their drawings, the residents of Ljubljansko polje and the surroundings focused particularly on the areas around pumping stations or included an area that is much wider than just Ljubljansko polje, mainly toward the south. It is gratifying that they are aware of another protection zone south of Ljubljansko polje, although it is drawn too far to the north in the Ljubljansko Barje moor. It is surprising that the residents of Iški vršaj and the surrounding area have such poor knowledge of regional conditions, outlining the area of Ljubljansko polje much less distinctly and mainly following the course of the Sava River. In Iški vršaj we detected a minor concentration around pumping stations, but the expansion of the area, especially eastwards to the eastern edge of Ig and northwards partly to Črna vas and Lipe and even as far as the southern Ljubljana expressway, is very evident.

In their work, geographers rely greatly on geographical divisions or the regions derived from them. Regrettably, our results indicate that with the exception of the Krim hills, those surveyed as a rule did not know the natural boundaries that determine the definition of water protection zones in Ljubljansko polje and Iški vršaj. Very often, those surveyed connected Ljubljansko polje and the Ljubljansko Barje moor across Rožnik, Castle Hill, and Golovec into a single area or could not distinguish Iški vršaj from the Ljubljansko Barje moor. Obviously, the statement that we get individuals' images that are in harmony with their perception of space but often very different from the objective environment is quite true. 
Water protection zones have existed for decades, since the first decree to protect the areas around pumping stations is already more than half a century old (Odlok... 1955). In spite of this, it is obvious that the regulations never really took hold since many people living in these areas have no knowledge of them and they do not actually limit people in their everyday lives and activities.

A lack of information and education are the key problems we face in both studied areas in all socioeconomic groups. We can state that people in general are still insufficiently informed and environmentally educated or aware about water as a natural resource to be willing or able to actively cooperate in the protection of water as a natural resource or participate in decision-making processes regarding land use plans for the preservation of the quality of water as existing declarations and adopted legislation allows and obliges them to.

\section{References}

Breg, M., Fridl, J., Kladnik, D., Smrekar, A. 2005: Vrednotenje nedovoljenih odlagališč odpadkov glede na nujnost njihove sanacije. Geografski vestnik 77-1, str. 89-101. Ljubljana.

Breznik, M. 1988: Analiza odlokov o zaščiti ljubljanskih virov pitne vode. Ljubljanski ekološki dnevi 88. Ljubljana.

Gams, I., Resnik Planinc, T., Saarinen, T. F. 1993: Poznavanje držav sveta pri slovenskih in tujih dijakih. Geografija v šoli 3, str. 118-129. Ljubljana.

Kladnik, D. 2002: Pomen in perspektive kmetijstva znotraj ljubljanskega avtocestnega obroča. Geografski vestnik 75-2, str. 35-52. Ljubljana.

Kladnik, D., Rejec Brancelj, I., Smrekar, A. 2002: Integralna obremenjenost prodnih ravnin Slovenije. V: Bufon, M. (ur.): Geografija in njene aplikativne možnosti. Dela 18, str. 635-648. Ljubljana.

Kladnik, D., Rejec Brancelj, I., Smrekar, A. 2003: Dung installations as dangerous point sources burdening the groundwater of Ljubljansko polje $=$ Gnojni objekti kot nevarni točkovni viri obremenjevanja podtalnice Ljubljanskega polja. Acta geographica Slovenica 43-2, str. 121-139. Ljubljana.

Klemenčič, M. M. 2002: Miselna slika pokrajin. V: Polič, M. (ur.), Repovš, G. (ur.): Spoznavni zemljevid Slovenije. Razprave Filozofske fakultete, str. 161-180. Ljubljana.

Natek, K. 2002: Risanje zemljevida Slovenije. V: Polič, M. (ur.), Repovš, G. (ur.): Spoznavni zemljevid Slovenije. Razprave Filozofske fakultete, str. 211-251. Ljubljana.

Natek, K. 2002: Odnos do domačega kraja (pokrajine) in njegovih (njenih) problemov. V: Polič, M. (ur.), Repovš, G. (ur.): Spoznavni zemljevid Slovenije. Razprave Filozofske fakultete, str. 211-251. Ljubljana.

Odlok o varstvenih pasovih vodnih virov v Ljubljani in ukrepih za zavarovanje voda. Uradni list SRS 18, 1977. Ljubljana.

Odlok o varstvu virov pitne vode. Uradni list RS 13, 1988. Ljubljana.

Odlok o zaščitnem pasu Mestnega vodovoda MOL. Uradni list LRS 3, 1955. Ljubljana.

Polič, M. 2002: Doumevanje okolja. V: Polič, M. (ur.), Repovš, G. (ur.): Spoznavni zemljevid Slovenije. Razprave Filozofske fakultete, str. 15-55. Ljubljana.

Rejec Brancelj, I. 2000: Okoljski učinki intenzivnega kmetovanja v rastlinjakih. V: Gabrovec, Matej (ur.), Orožen Adamič, Milan (ur.): Ljubljana: geografija mesta, str. 185-193. Ljubljana.

Rejec Brancelj, I. 2003: Kmetijstvo v Sloveniji z vidika obremenjevanja okolja. Geografski vestnik 75-2, str. 53-64. Ljubljana.

Rejec Brancelj, I. (ur.), Smrekar, A. (ur.), Kladnik, D. 2005: Podtalnica Ljubljanskega polja, Geografija Slovenije 10. Ljubljana.

Smrekar, A. 2005: Zavest o rabi vode kot naravnega vira. Doktorska disertacija, Fakulteta za humanistične študije Koper Univerze na Primorskem. Koper.

Smrekar, A., Kladnik, D. 2004: Popis vodnjakov in vrtin v zasebni lasti na območju vodnih virov Mestne občine Ljubljana. Elaborat, Geografski inštitut Antona Melika ZRC SAZU. Ljubljana.

Toš, N. 1988: Metode družboslovnega raziskovanja. Državna založba Slovenije. Ljubljana.

Urbanc, M., Breg, M. 2005: Gravel plains in urban areas: gravel pits as an element of degraded landscapes = Prodna ravnina $\mathrm{v}$ mestnem prostoru: gramoznice kot prvina degradirane pokrajine. Acta geographica Slovenica 45-2, str. 35-61. Ljubljana.

Uredba o vodovarstvenem območju za vodno telo vodonosnika Ljubljanskega polja. Uradni list RS 126, 2004. Ljubljana. 


\section{Z risanjem spoznavnih zemljevidov do poznavanja varstvenih pasov virov pitne vode}

UDK: 628.1:912(497.4)

COBISS: 1.01

IZVLEČEK: Med 900 osebami v mestnem okolju Ljubljanskega polja in v primestnem okolju na Iškem vršaju smo želeli ugotoviti njihovo poznavanje varstvenih pasov virov pitne vode. Uporabili smo metodi anketiranja in risanja spoznavnih zemljevidov. Malo manj kot polovica je prepričanih, da živijo na varstvenih pasovih. Deleža tako mislečih na varstvenih pasovih na Ljubljanskem polju (dve petini) in na Iškem vršaju (dve tretjini) se precej razlikujeta. Meje varstvenih pasov je na priložen zemljevid zarisalo samo 280 oseb, torej malo manj kot tretjina zaprošenih. Na Ljubljanskem polju je največja zarisana zgostitev varstvenih pasov malce severno od najstarejšega in največjega črpališča Kleče. Drugo najmočnejšo zgostitev opazimo na Iškem vršaju in sicer v neposredni okolici črpališča Brest.

KLJUČNE BESEDE: pitna voda, vodovarstveno območje, anketa, spoznavni zemljevid, Ljubljansko polje, Iški vršaj, Slovenija.

Uredništvo je prejelo prispevek 27. februarja 2006.

NASLOV:

Aleš Smrekar, dr.

Geografski inštitut Antona Melika

Znanstvenoraziskovalni center Slovenske akademije znanosti in umetnosti

Gosposka ulica 13, SI - 1000 Ljubljana, Slovenija

E-pošta: ales.smrekar@zrc-sazu.si

\section{Vsebina}

1 Uvod 25

2 Metode 26

3 Rezultati 27

3.1 Vsebinsko poznavanje varstvenih pasov virov pitne vode - anketa 27

3.2 Prostorsko poznavanje varstvenih pasov

4 Sklep

5 Viri in literatura $\quad 31$ 


\section{Uvod}

Zagotavljanje dovolj velike količine pitne vode je v Evropi in v Sloveniji odvisno predvsem od zalog podzemne vode. Vemo, da se na aluvialnih ravninah, pod katerimi so največje zaloge pitne vode, križajo zelo različni interesi, vendar lahko $\mathrm{z}$ ustreznim upravljanjem $\mathrm{z}$ vodami nadzorujemo in usmerjamo posege $\mathrm{v}$ prostor (Kladnik in sodelavci 2002; Rejec Brancelj 2003; Urbanc, Breg 2005).

Med najizrazitejša sodobna prostorska nasprotja lahko uvrščamo odnos med mestno rabo prostora in varovanjem virov pitne vode. Bolj ko se mesto s svojimi funkcijami razvija, bolj sta prizadeti kakovost in količina za pitje primernih vodnih zalog.

Bogate zaloge podtalnice $\mathrm{v}$ neposredni bližini in celo pod precejšnjim delom Ljubljane, ki so ocenjene na 100 milijonov $\mathrm{m}^{3}$, oziroma dinamične zaloge (vrednost najmanjšega pretoka) na $2 \mathrm{~m}^{3} / \mathrm{sek}$, so naravni vir regionalnega pomena (Rejec Brancelj in sodelavci 2005). Tudi več kot sto let po ustanovitvi centralnega vodovodnega sistema je podtalnica Ljubljanskega polja še vedno najpomembnejši vir pitne vode za oskrbo Ljubljane. Daje $90 \%$ potrebne količine, preostalih $10 \%$ pa se načrpa v bližini naselja Brest iz vodonosnika Iškega vršaja na južnem obrobju Ljubljanskega barja, ki pa ni več v Mestni občini Ljubljana, temveč v sosednji občini Ig.

Pitno vodo iz podtalnice Ljubljanskega polja pridobivajo v štirih črpališčih: Kleče, Šentvid, Hrastje in Jarški prod. Prvi dve sta na zahodnem delu Ljubljanskega polja med strnjeno pozidanimi mestnimi zemljišči na jugu, zahodu in vzhodu ter Savo na severu. Vmes sta kmetijsko še vedno dejavni nekdaj samostojni vaški naselbini Kleče in Savlje. Črpališče Hrastje je v vzhodnem delu Ljubljanskega polja, med moščansko industrijsko-servisno cono na jugu in Šmartinsko cesto na desnem bregu Save. Crpališče Jarški prod je na levem bregu reke, južno od črnuške industrijsko-obrtno-servisne cone, ki se ob zahoda proti vzhodu vleče med Črnučami in Nadgorico. Peto črpališče za oskrbo Ljubljane je na območju Ljubljanskega barja oziroma njegovem Iškem vršaju, to je črpališče Brest, ki leži južno od istoimenskega naselja.

Slika 1: Varstveni pasovi na Ljubljanskem polju in lškem vršaju iz leta 1988 (Odlok ... 1988).

Glej angleški del prispevka.

Varstvene pasove črpališč na Ljubljanskem polju so prvič določili leta 1955 (Odlok ... 1955). Bili so odločilni za varovanje vodnega vira, ker so omejili širitev mesta v bližino črpališč (Breznik 1988). Omejitve so razmeroma dosledno upoštevali, po letu 1966 pa so znotraj ožjega območja dopustili gradnjo individualnih hiš in novih sosesk; nastali so vzhodni deli Savelj, južni del Kleč, del Tomačevega in industrijska cona ob Letališki cesti. Nov odlok o varstvenih pasovih je bil sprejet leta 1977 (Odlok ... 1977). S tem odlokom je bil varstveni pas določen tudi za črpališče Jarški prod. Določena sta bila še širši (tretji) in vplivni (četrti) varstveni pas, ki sta obsegala območje, $s$ katerega prenikajo ali dotekajo vode neposredno v podtalnico. Ker nista bila prednostno namenjena varovanju, je bila na njiju dovoljena stanovanjska in druga zidava s priključitvijo na javno kanalizacijsko omrežje in z zaščito pred pronicanjem škodljivih snovi $\mathrm{v}$ podtalnico.

V prispevku obravnavana varstvena pasova virov pitne vode na Ljubljanskem polju in prvič tudi Iškem vršaju sta bila določena z Odlokom o varstvu virov pitne vode (Odlok ... 1988), ki na Ljubljanskem polju v primerjavi s prej veljavnim odlokom ni prinesel bistvenih sprememb. Ta odlok še vedno velja na Iškem vršaju, medtem ko je bila za območje Ljubljanskega polja sprejeta nova Uredba na vodovarstvenem območju za vodno telo vodonosnika Ljubljanskega polja (Uredba ... 2004). Glede na to, da v prispevku obravnavamo varstvene pasove virov pitne vode, kot jih predvideva odlok iz leta 1988, uporabljamo že zastarel izraz varstveni pas vira pitne vode, namesto sedaj uveljavljenega izraza vodovarstveno območje.

Območje je razdeljeno na tri varstvene pasove virov pitne vode:

- prvi ali najožji varstveni pas je namenjen izključno objektom za oskrbo s pitno vodo (41,35 ha na Ljubljanskem polju in 13,8 ha na Iškem vršaju);

- drugi ali ožji varstveni pas s strogim režimom varovanja je namenjen neposredni zaščiti črpališč pred onesnaženjem (skupaj 1942,71 ha na Ljubljanskem polju in 520,7 ha na Iškem vršaju);

- tretji ali širši varstveni pas z blagim režimom varovanja je namenjen varovanju toka podtalnice proti črpališčem (skupaj 3618,95 ha na Ljubljanskem polju in 521,3 ha na Iškem vršaju);

Celosten pristop gospodarjenja $\mathrm{z}$ vodo teži k ekonomski učinkovitosti na eni strani in k sonaravnemu gospodarjenju na drugi. Vse bolj pomembni so tudi dokumenti, ki govorijo o doseganju družbenega konsenza pri odločanju o okolju z vključevanjem vseh interesnih skupin v odločevalski proces. 
Predpogoj za aktivno sodelovanje v procesih odločanja o načrtih rabe prostora pa tudi za ohranjanje ter varovanje kakovosti vodnih virov in vode nasploh je okoljska ozaveščenost o vodi kot naravnem viru.

Splošno prepričanje je, da je prebivalstvo Ljubljane in okolice okoljsko dovolj ozaveščeno. Vendar se ta stereotip kaj hitro poruši, ko se spomnimo na številna neurejena odlagališča odpadkov, nevodotesne greznice in gnojne objekte, neustrezno ravnanje s fitofarmacevtskimi sredstvi v kmetijstvu, nenadzorovano individualno črpanje vode (Kladnik 2002; Rejec Brancelj 2000; Kladnik in sodelavci 2003; Smrekar in Kladnik 2004; Breg in sodelavci 2005), na katere pomembno vplivajo zlasti posamezniki. Dosedanje izkušnje kažejo, da je ozaveščenost tesno povezana s socialnoekonomsko sestavo, je pa tudi rezultat dolgotrajnega uspešnega informiranja in izobraževanja prebivalcev. Prebivalstvo štejemo za povzročitelja in sprejemnika sprememb v okolju ter aktivnega oziroma pasivnega preoblikovalca pokrajine.

V prispevku smo si zastavili cilj, da ugotovimo in ovrednotimo poznavanje varstvenih pasov virov pitne vode.

\section{Metode}

V okviru širše zastavljene študije (Smrekar 2005) smo med drugim poskušali raziskati, kako lokalno prebivalstvo dojema okolje, v katerem živi. Glede na to, da anketiranci prihajajo iz različnih okolij, smo ugotavljali različnosti in podobnosti med posameznimi skupinami, predvsem pa vzroke za večjo oziroma manjšo okoljsko ozaveščenost.

Zanimalo nas je, koliko prebivalci poznajo varstvene pasove virov pitne vode, za kar smo uporabili metodi anketiranja in spoznavnih zemljevidov.

Slika 2: Območji anketiranja na obravnavanih varstvenih pasovih virov pitne vode in njihovih obrobjih.

Glej angleški del prispevka.

Preučevali smo populacijo, ki se oskrbuje s pitno vodo iz ljubljanskega vodovodnega sistema. Vključeni prebivalci so v času trajanja študije (2003 in 2004) živeli na varstvenih pasovih virov pitne vode na Ljubljanskem polju in Iškem vršaju (Odlok ... 1988) ali v njihovi bližini.

Anketiranje je metoda empiričnega vpogleda v izbrano populacijo in njen vzorec (Toš 1988). Anketirali smo 900 oseb. Dve tretjini anket smo opravili v mestnem okolju Ljubljanskega polja in tretjino v primestnem okolju na Iškem vršaju. Tretjina (300) anket je bila opravljena med »aktivnimi« obremenjevalci podtalnice na ožjem pasu virov pitne vode ( 100 kmetovalcev in 100 vrtičkarjev na Ljubljanskem polju ter 100 kmetovalcev na Iškem vršaju), tretjina (300) med »pasivnimi« obremenjevalci (prebivalci, ki »le« živijo na tem območju) na širšem pasu virov pitne vode, tretjina (300) pa med uporabniki pitne vode iz obravnavanih črpališč, ki ne živijo na varstvenih pasovih virov pitne vode. Reprezentativni vzorec prebivalcev smo dosegli s sledenjem dvema demografskima kriterijema: starostni in spolni sestavi obravnavanih oseb.

V raziskavo je vključena v geografiji doslej redkeje uporabljena metoda spoznavnih zemljevidov (Gams in sodelavci 1993; Klemenčič 2002; Natek 2002a; Natek 2002b), s katero se pogosteje srečujejo psihologi. Spoznavni zemljevidi so ob povsem teoretičnih razmislekih nastajali in se uporabljali predvsem zaradi praktičnih načrtovalskih vprašanj. Ta so se nanašala predvsem na rabo prostora in razporeditev virov pa tudi na povezanost s predstavami o okolju. Raziskave spoznavnih zemljevidov v razmerju med človekom in okoljem med drugim lahko prispevajo $\mathrm{k}$ bolj razumni rabi naravnih virov, spodbujajo posameznike $\mathrm{v}$ vpletenost pri razvoju in načrtovanju učinkovitejšega izvajanja sprememb ter pomagajo pri ohranjanju in beleženju okoljskih zaznav (Polič 2002; po Wyhte).

Spoznavni zemljevidi, torej postopki, s katerimi poskušamo ugotoviti, kako si ljudje predstavljajo prostorske odnose in značilnosti okolja, so lahko pomembno sredstvo za pridobivanje informacij, pomembnih za ugotavljanje stanja in na tej podlagi za nadaljnje načrtovanje. Spoznavni zemljevidi nudijo vsaj dve vrsti obvestil, in sicer:

- neposredno zaznavno izkušnjo in

- spoznavno predelavo osebne izkušnje.

Za to poznamo več metod. Odločili smo se, da bomo podatke pridobili z družbenoprostorskimi obrazci. To je bolj strukturirana oblika raziskovanja spoznavnih zemljevidov. Anketiranci so morali obkrožiti tisto območje, za katerega so menili, da je razglašeno za varstveni pas virov pitne vode za oskrbo prebivalstva. 
Pri risanju tovrstnih zemljevidov se nam posameznikove slike okolja pokažejo kot rezultati spoznavnih preslikav, ki vsebujejo položajne informacije (meje varstvenih pasov). Posameznikova slika okolja je usklajena z njegovimi pogledi na uporabo tega prostora. Razlikujemo geografsko in vedenjsko okolje, saj vsi, ki živijo v istem geografskem okolju, živijo v različnih vedenjskih okoljih in si informacije pridobivajo $\mathrm{z}$ vsemi čutili (Polič 2002).

Poleg odgovarjanja na vprašanja, zastavljena v anketi, smo vsakega anketiranca osebno zaprosili, da je zarisal mejo varstvenega pasu oziroma meje več pasov virov pitne vode za oskrbo prebivalcev Ljubljane in okolice na črno-bel zemljevid formata A3 v merilu približno 1:73.000 širšega ljubljanskega območja s skrajnimi točkami na severozahodu pri Zbiljah, na severovzhodu blizu Prevoj pri Šentvidu, na jugozahodu nedaleč od Smrekovca pri Rakitni in na jugovzhodu ob Kremenici pri Predolah.

Še pred tem smo anketirancem pojasnili, da podtalnico pred onesnaževanjem varuje Odlok o varstvu virov pitne vode ter da je treba zagotavljati primerne razmere za zdravstveno ustreznost vode in tudi njeno količino.

Meje varstvenih pasov virov pitne vode je od 900 anketirancev zarisalo samo 280 oseb, torej malo manj kot tretjina $(31,1 \%)$, od tega 163 oziroma četrtina $(27,1 \%)$ zaprošenih na Ljubljanskem polju (slabe tri petine ali 58,2\% od vseh zarisov) in 117 oziroma slabi dve petini (39,0 \%) zaprošenih na Iškem vršaju ter prav tako dve petini $(41,7 \%)$ vseh zarisov. Odziv ocenjujemo kot dober, saj je bilo vprašanje zastavljeno tako, da so risali le tisti, ki naj bi vedeli, kje meje varstvenih pasov virov pitne vode sploh potekajo.

Kartografsko gradivo je pripravljeno z računalniškim programom ARC GIS.

\section{Rezultati}

\subsection{Vsebinsko poznavanje varstvenih pasov virov pitne vode - anketa}

Za ugotavljanje seznanjenosti anketirancev s proučevano problematiko je ključen dokument Odlok o varstvu virov pitne vode (Odlok ... 1988), ki vključuje Ljubljansko polje in Iški vršaj. Glede na to, da smo anketo opravljali leta 2003, torej še pred sprejemom nove uredbe, ki pa velja le za Ljubljansko polje, je logično, da smo pri študiji upoštevali meje takratnih varstvenih pasov virov pitne vode. Po več kot 15 letih veljavnosti odloka smo spraševali anketirance, ali živijo (oziroma imajo vrtiček) na z odlokom razglašenem varstvenem pasu virov pitne vode za oskrbo Ljubljane in okolice.

Slika 3: Mnenje anketirancev o tem, ali živijo na z odlokom razglašenem varstvenem pasu virov pitne vode za oskrbo Ljubljane in okolice (Smrekar 2005; $\mathrm{N}=900$ ).

Glej angleški del prispevka.

Ob upoštevanju odgovorov vseh anketiranih oseb (z varstvenih pasov in zunaj njih) smo ugotovili, da jih je 439 oziroma $48,8 \%$ pravilno odgovorilo oziroma so bili prepričani, da živijo ali imajo vrtičke oziroma ne živijo na varstvenih pasovih virov pitne vode. Polovica tistih, ki živijo zunaj varstvenih pasov (50,5\% na Ljubljanskem polju in 47,0 \% na Iškem vršaju), je prepričanih, da ne živijo na zavarovanih območjih. Skoraj tretjina $(31,2 \%)$ pa ne ve, kaj bi na zastavljeno vprašanje odgovorila.

Ob pregledu rezultatov zgolj na varstvenih pasovih ugotavljamo, da je tam malo manj kot polovica $(48,5 \%)$ prepričanih, da živijo na njih. Deleža tako mislečih na Ljubljanskem polju (samo $39,0 \%)$ in na Iškem vršaju $(67,5 \%)$ se močno razlikujeta. Kmetovalci najbolje vedo, da živijo na varstvenih pasovih, vendar je razmerje med obema območjema obrnjeno; takšnih je na Ljubljanskem polju več kot tri četrtine (77,0 \%), na Iškem vršaju pa samo nekaj več kot dve tretjini (68,0\%). Očitno je, da so kmetovalci na Ljubljanskem polju bolj na udaru raznih javnih služb in jim je povsem jasno, kje živijo. Kmetovalci na Iškem vršaju omenjeno problematiko slabše poznajo. To je verjetno posledica manj intenzivnega sodelovanja z raznimi službami in tudi pomanjkljivega medobčinskega sodelovanja med Mestno občino Ljubljana in občino Ig.

Nižji delež pravilnih odgovorov med vrtičkarji $(56,0 \%)$ si lahko razlagamo le tako, da ti anketiranci slabše poznajo območja, kjer imajo vrtičke, saj ti pogosto niso v bližini njihovih bivališč. Najnižji delež pravilnih odgovorov je na širšem varstvenem pasu na Ljubljanskem polju, saj se jih le malo več kot desetina $(11,5 \%)$ zaveda, da živijo na varstvenem pasu, dobra tretjina (kar 36,5\%) pa je prepričanih, da sploh ne živijo na varstvenih pasovih. Medtem ko ljudje na Ljubljanskem polju nekako še poznajo ožja območja 
črpališč, za katera vedo ali vsaj sklepajo, da so z uradnim aktom zavarovana območja, je širša okolica teh objektov v zavesti ljudi že tako oddaljena od črpališč, da ne opazijo nobene povezave več. Povsem jasno je, da jih nihče sistematično ne seznanja, kje živijo.

Od anketirancev, ki so pravilno odgovorili na prejšnje vprašanje, če živijo na varstvenem pasu, smo pričakovali tudi, da navedejo ime tega pasu. Takšnih, ki so vsaj približno pravilno navedli ime (ime črpališča, območja oziroma celotnega varstvenega pasu), je med vsemi malo več kot četrtina (26,5\%), od tega jih je, kljub pol manjšemu vzorcu, kar blizu polovica na Iškem vršaju (45,5\%). Med pravilna poimenovanja smo šteli na primer na Iškem vršaju Ljubljanski vodovod, Barje, Iški vršaj, Brest, Ig in Matena, na Ljubljanskem polju pa Ljubljanski vodovod, Ljubljana, Šentvid, Stegne, Kleče, Savlje, Črnuče, Jarški prod, Savski prod in Hrastje. Presenetljivo majhen je delež približno pravilnih poimenovanj med kmetovalci na Iškem vršaju (36,0 \%). Anketiranci na širšem varstvenem pasu virov pitne vode na Ljubljanskem polju $(3,0 \%)$ so skoraj brez, pogojno rečeno, pravilnih odgovorov.

\subsection{Prostorsko poznavanje varstvenih pasov virov pitne vode - spoznavni zemljevidi}

Tudi s tem poizvedovanjem smo želeli ugotoviti, ali obravnavani prebivalci vedo, da živijo na območjih, ki so z ustreznimi pravnimi akti zaščitena kot območja varstva virov pitne vode. Tokrat pa nas ni zanimalo zgolj vedenje, temveč predvsem prostorsko poznavanje meja.

S spoznavnimi zemljevidi smo torej pridobili spoznavno predelavo osebne izkušnje. Za sodelovanje se je odločilo 280 od 900 anketirancev, kar je malo manj kot tretjina oziroma 31,1\%. Tako imamo med 280 narisanimi mejami varstvenih pasov šest desetin z Ljubljanskega polja $(58,2 \%)$ in štiri desetine z Iškega vršaja $(41,8 \%)$. Čeprav to razmerje ne odraža razmerja opravljenih anket na obeh obravnavanih območjih (600:300), je z vidika interpretacije ugodnejše, saj bi težje vizualno razlikovali med dvema tretjinama zarisanih meja anketirancev z Ljubljanskega polja in eno tretjino z Iškega vršaja. Število zarisovalcev meja z obeh območij pa glede na malo prej predstavljeno mnenje anketirancev o tem, ali živijo na z odlokom razglašenem varstvenem pasu, sploh ne preseneča.

Preglednica 1: Sodelujoči anketiranci pri risanju varstvenih pasov virov pitne vode za oskrbo Ljubljane in okolice (Smrekar 2005; N = 280).

\begin{tabular}{|c|c|c|c|}
\hline & $\begin{array}{l}\text { skupaj } \\
\text { risarjev }\end{array}$ & $\begin{array}{l}\text { delež risarjev od vseh } \\
\text { anketirancev v skupini }\end{array}$ & $\begin{array}{l}\text { delež risarjev od } \\
\text { vseh anketirancev }\end{array}$ \\
\hline $\begin{array}{l}\text { Ljubljansko polje } \\
\text { kmetovalci }\end{array}$ & 38 & $38.0 \%$ & $42 \%$ \\
\hline Ljubljansko polje & & & 4,2710 \\
\hline vrtičkarji & 25 & $25,0 \%$ & $2,8 \%$ \\
\hline $\begin{array}{l}\text { Ljubljansko polje } \\
\text { ožii varstveni pas - skupai }\end{array}$ & & & \\
\hline $\begin{array}{l}\text { ožji varstveni pas - skupaj } \\
\text { Ljubljansko polje }\end{array}$ & 63 & $31,5 \%$ & $7,0 \%$ \\
\hline širši varstveni pas & 65 & $32,5 \%$ & $7,2 \%$ \\
\hline $\begin{array}{l}\text { Ljubljansko polje } \\
\text { ožji in širši varstveni pas } \\
\text { Ljubljansko polje }\end{array}$ & 128 & $32,0 \%$ & $14,2 \%$ \\
\hline $\begin{array}{l}\text { zunaj varstvenih pasov } \\
\text { Ljubljansko polje }\end{array}$ & 35 & $17,5 \%$ & $3,9 \%$ \\
\hline $\begin{array}{l}\text { skupaj } \\
\text { lški vršaj }\end{array}$ & 163 & $27,2 \%$ & $18,1 \%$ \\
\hline $\begin{array}{l}\text { ožji varstveni pas } \\
\text { lški vršaj }\end{array}$ & 45 & $45,0 \%$ & $5,0 \%$ \\
\hline $\begin{array}{l}\text { širši varstveni pas } \\
\text { lški vršaj }\end{array}$ & 45 & $45,0 \%$ & $5,0 \%$ \\
\hline $\begin{array}{l}\text { ožji in širši varstveni pas } \\
\text { Iški vršaj }\end{array}$ & 90 & $45,0 \%$ & $10,0 \%$ \\
\hline $\begin{array}{l}\text { zunaj varstvenih pasov } \\
\text { Iški vršaj }\end{array}$ & 27 & $27,0 \%$ & $3,0 \%$ \\
\hline skupaj & 117 & $39,0 \%$ & $13,0 \%$ \\
\hline skupaj & 280 & $31,1 \%$ & $31,1 \%$ \\
\hline
\end{tabular}


Slika 4: Varstveni pasovi virov pitne vode za oskrbo Ljubljane in okolice, kot so jih narisali vsi anketiranci (Smrekar 2005; N = 280). Glej angleški del prispevka.

Pogled na zemljevid vseh narisanih območij nam pokaže določene zgostitve. Na Ljubljanskem polju je največja zgostitev na območju naselja Kleče severno od istoimenskega črpališča, z veliko koncentracijo odgovorov. Zgostitev se dokaj koncentrično, vendar v zelo majhnem premeru, širi od naselja proti črpališčema Kleče in Šentvid. Za slednjo le naključno, saj iz drugih odgovorov lahko sklepamo, da prebivalci slabo poznajo črpališče Šentvid. Zgostitveni »oblak« se proti jugovzhodu precej natrga, vendar ga ponovno zaznamo v obliki manj intenzivno zgoščene elipse okoli črpališča Hrastje. Severno od njega na levem bregu Save pa pozornemu opazovalcu ne uide sicer manj izrazita, vendar še vedno prepoznavna zaznava elipse okoli črpališča Jarški prod. Dve elipsasti obliki, ena pod drugo, sta verjetno posledica vidne meje v prostoru, ki jo predstavlja reka Sava. Lahko pa bi ju povezali v enoten, manj dominanten krog, kot se širi okoli črpališča Kleče.

Južni del Ljubljanskega polja, lahko bi rekli večina širšega varstvenega pasu, pa v zavesti ljudi ni zakoreninjen kot varovano območje. Če so anketiranci bolj na široko vrisovali meje varstvenih pasov, potem so to v večini primerov storili tako, da so poleg Ljubljanskega polja vključili še vzpetine, kot so Rožnik, Grad in del Golovca, na Barju pa se približali severnemu robu Iškega vršaja.

Drugo najmočnejšo zgostitev opazimo na Iškem vršaju, in sicer v neposredni okolici črpališča Brest, katere meje se gostijo na zahodu ob vznožju Krimskega hribovja. Anketirancem se očitno zdi, da predstavlja mejo varstvenega pasu rob med ravnim in vzpetim svetom. Malce bolj zabrisano, čeprav še vedno dokaj izrazito, se zgostitveni »oblak« širi proti jugu in vzhodu vršaja. Zanimivo, zgostitveni »oblak« sega precej tudi na Barje, saj na vzhodu doseže vzhodni del Iga, na severu pa vse do južne ljubljanske obvoznice.

Iški Vintgar anketiranci manj pogosto povezujejo z varovanim območjem.

Še zanimivejša je razčlenitev odgovorov po posameznih skupinah. Anketiranci na ožjem varstvenem pasu, torej kmetovalci in vrtičkarji, se očitno zavedajo, kje so ožji varstveni pasovi, vendar to pogosto enačijo z zunanjimi mejami varovanih območij.

Slika 5: Varstveni pasovi virov pitne vode za oskrbo Ljubljane in okolice, kot so jih narisali anketirani kmetovalci in vrtičkarji z Ljubljanskega polja. (Smrekar 2005; N = 63).

Glej angleški del prispevka.

Do velike zgostitve črt v obliki kroga prihaja pri naselju Kleče in dveh elips pri črpališčih Hrastje in Jarški prod. Manj izrazito je zaznavno širše območje.

Južno od Ljubljane zaznamo novo zgostitev, ki je širše razporejena, njeno središče pa vendar gravitira severno od Iškega vršaja na območju Črne vasi in Lip. Kmetovalci so zarisali mejo precej na široko; v nekaterih primerih sega od južnega roba Ljubljanskega polja vse do južnega roba Iškega vršaja. Med vrtičkarji je ta meja bistveno bolj zgoščena v ožjem pasu od sredine Ljubljanskega barja do sredine Iškega vršaja, resda $\mathrm{z}$ manjšim številom ponovitev.

Slika 6: Varstveni pasovi virov pitne vode za oskrbo Ljubljane in okolice, kot so jih narisali anketiranci s širšega varstvenega pasu virov pitne vode Ljubljanskega polja in zunaj njega (Smrekar 2005; N = 100).

Glej angleški del prispevka.

Anketiranci s širšega varstvenega pasu virov pitne vode Ljubljanskega polja vidijo mejo varovanega območja povsem drugače. Pri njih ne zaznamo, razen redkih izjem v okolici črpališča Kleče, nobenih zgostitev na manjših območjih. Predvsem lahko sledimo veliki izrisani pokončni elipsi od severnega roba Ljubljanskega polja vse do južnega roba Iškega vršaja z zaznanim razlikovanjem dveh območij po sredini Barja.

Meje je bilo pripravljenih zarisati le 17,5\% anketirancev z roba Ljubljanskega polja, ki živijo zunaj varstvenih pasov virov pitne vode. Pokazalo se je, da dokaj dobro poznajo lokacijo črpališča Brest (od tam dobivajo večino vode) in malo manj Hrastja ter Jarškega proda, pri črpališčih Kleče in Šentvid pa so z risanjem enega kroga verjetno zopet dokazali, da ne poznajo natančne lokacije črpališča Kleče, Šentvid pa jim je sploh manj poznan. Če posplošimo, ugotovimo, da so varstvene pasove na Ljubljanskem polju zožili predvsem na njegovi severni in vzhodni strani vzdolž reke Save, varstvene pasove na Iškem vršaju pa so v koničasti obliki razširili proti severu, vse do sredine Barja. 
Slika 7: Varstveni pasovi virov pitne vode za oskrbo Ljubljane in okolice, kot so jih narisali anketirani kmetovalci z ľskega vršaja (Smrekar 2005; $\mathrm{N}=45$ ).

Glej angleški del prispevka.

Anketiranci z ožjega varstvenega pasu virov pitne vode na Iškem vršaju so pokazali zelo nenavadno poznavanje varstvenih pasov, še posebej v domači pokrajini. Glede na njihovo zelo solidno poznavanje dejstva, da živijo na varstvenem pasu, bi pričakovali, da jim je tudi prostorska slika bolj jasna. V primerjavi s kmetovalci z Ljubljanskega polja, ki so se omejili na risanje mej v neposrednih zaledjih črpališč, je med tukajšnjimi kmetovalci neposredna okolica črpališča Brest zarisana le izjemoma. Izrisi se ob zahodnem in južnem robu Iškega vršaja praviloma naslanjajo na vznožje Krimskega hribovja, čeprav pogosto segajo tudi proti jugozahodu visoko v hribovje. Presenetljivo na široko je pogosto omejeno območje zlasti proti severu, kjer sega skoraj do južne ljubljanske obvoznice, in zahodu, kjer sega skoraj do zahodnega roba Vnanjih Goric. Druga zgostitev meja je v širšem pasu Save na Ljubljanskem polju z nakazanimi razmejitvami med posameznimi ožjimi zaledji črpališč. Veliko kmetovalcev z Iškega vršaja vidi Iški vršaj in Ljubljansko polje kot enotno varovano območje, ki zajema tudi vmes ležeče Barje. Prav nobeden pa očitno ni seznanjen, da sega varstveni pas na Iškem vršaju tudi globoko v Iški Vintgar.

Slika 8: Varstveni pasovi virov pitne vode za oskrbo Ljubljane in okolice, kot so jih narisali anketiranci s širšega varstvenega pasu virov pitne vode lškega vršaja in zunaj njega (Smrekar 2005; $N$ = 72).

Glej angleški del prispevka.

Anketiranci s širšega varstvenega pasu virov pitne vode na Iškem vršaju najbolje med vsemi obravnavanimi skupinami poznajo svoje varovano območje. Zelo dobro so velikokrat narisani zahodna in južna meja pa tudi krak, ki sega proti Iškemu Vintgarju, medtem ko na severu in vzhodu meji uhajata navzven. Samo nekaj je primerov, ko mejo širokopotezno zarisujejo proti sredini Barja, prav nobeden pa ne povezuje tega območja z Ljubljanskim poljem v enotno varovano območje. Po mnenju tistih, ki menijo, da je Ljubljansko polje varovano, očitno poteka meja na Ljubljanskem polju izključno vzdolž reke Save z razmejenimi območji okoli črpališč.

Anketiranci zunaj varstvenih pasov virov pitne vode z roba Iškega vršaja so se komaj četrtinsko $(27,0 \%)$ odzvali vabilu za risanje meja, pa še ti kažejo zelo slabo poznavanje razmer na Ljubljanskem polju, saj so praviloma zarisali meje preveč proti severu in vzhodu. Njihovo poznavanje razmer na Iškem vršaju je precej boljše, čeprav so, zanimivo velikokrat tudi oni omejevali območje bolj proti vzhodu in severu, torej so očitno menili, da tudi sami živijo na varovanem območju.

Osnovnošolsko izobraženi so narisali eno petino $(21,2 \%)$ vseh spoznavnih zemljevidov, medtem ko predstavniki drugih treh izobrazbenih skupin po tri desetine $(32,8 \%, 29,6 \%$ in $30,5 \%)$. V samem poznavanju problematike med različnimi skupinami nismo uspeli zaznati bistvenih odstopanj.

\section{Sklep}

Rezultati kažejo, da na Iškem vršaju precej večji delež anketirancev kot na Ljubljanskem polju ve, da živijo na varstvenih pasovih virov pitne vode. To je verjetno posledica manjšega zaščitenega območja in bližine črpališča kot pomembnega objekta v njihovi okolici. Na drugi strani pa je na Ljubljanskem polju več kot petkrat večje zaščiteno območje, ki z oddaljenostjo od črpališča v zavesti ljudi izgublja pomen, poleg tega črpališča v mestnem okolju niso tako izstopajoči objekti kot v bolj ruralnem.

Zaskrbljujoče je nepoznavanje kmetovalcev na Iškem vršaju, saj vemo, da jih kmetijski pospeševalci stalno informirajo o dovoljenih opravilih na varstvenih pasovih. Nedvomno so manj izpostavljeni še bolj agresivnim pritiskom s strani raznih strokovnih služb kot kmetovalci na Ljubljanskem polju, kar pa se kaže v boljšem poznavanju odloka.

Spoznavni zemljevidi so vsekakor primerna dopolnitev klasičnega geografskega anketiranja. Odziv ni bil velik, najbrž je to posledica skromnejše prostorske predstave ljudi nasploh in verjetno zlasti nepoznavanja predstavljene problematike. Pokazale so se zakonitosti. Prebivalci Ljubljanskega polja in okolice so se pri risanju osredotočili zlasti na območja okoli črpališč ali pa zajeli območje, ki je precej širše od samega Ljubljanskega polja, predvsem proti jugu. Pohvalno je, da imajo v zavesti še eno varovano območje južno od Ljubljanskega polja, resda zarisano preveč severno, torej na Barju. Presenetljivo je, da prebivalci 
Iškega vršaja in okolice slabo poznajo regionalne razmere, saj so precej manj izrazito omejevali območje Ljubljanskega polja, kolikor pa so ga že, so sledili predvsem toku Save. Na Iškem vršaju sicer zasledimo manjšo osredotočenost okoli črpališč, vendar je bolj opazna razširitev območja zlasti proti vzhodu do vzhodnega roba Iga, in proti severu, deloma do Črne vasi in Lip, deloma celo do južne ljubljanske obvoznice.

Geografi se pri svojem delu zelo naslanjamo na členitve oziroma regije. Žal nam tokratni rezultati kažejo, da z izjemo Krimskega hribovja anketiranci praviloma niso zaznali niti naravnih meja, ki so pogojevale določitev varstvenih pasov virov pitne vode tako na Ljubljanskem polju kot na Iškem vršaju. Zelo pogosto so anketiranci Ljubljansko polje in Barje prek Rožnika, Gradu in Golovca povezali v enotno območje oziroma niso znali ločiti Iškega vršaja od Ljubljanskega barja. Očitno je povsem na mestu trditev, da se nam pokažejo posameznikove slike, ki so usklajene z njegovim videnjem prostora, to pa je marsikdaj zelo drugačno od objektivnega okolja.

Varstveni pasovi virov pitne vode oziroma najnovejša vodovarstvena območja imajo že večdesetletno tradicijo, saj je prvi odlok, ki je varoval območja okoli črpališč, star že pol stoletja (Odlok ... 1955). Kljub temu ti predpisi očitno niso dejansko nikoli povsem zaživeli, saj jih precej ljudi, ki živi na teh območjih, sploh ne pozna in jih torej pri njihovem vsakdanjem življenju in ravnanju ne omejujejo.

Pomanjkljivo informiranje in izobraževanje sta ključna problema, s katerima se soočamo na obeh obravnavanih območjih v vseh socialnoekonomskih skupinah. Zatrdimo lahko, da so ljudje na splošno še vedno nezadostno informirani, okoljsko izobraženi in ozaveščeni o vodi kot naravnem viru, da bi želeli in bili zmožni dejavno sodelovati pri varovanju vode kot naravnega vira in v procesih odločanja o načrtih rabe prostora za ohranitev kakovostne vode, kar jim omogočajo in h čimer jih zavezujejo obstoječe deklaracije ter sprejeta zakonodaja.

\section{Viri in literatura}

Glej angleški del prispevka. 